\title{
Genetic Improvement of Catharanthus roseus L. for Abiotic Stress Tolerance using HVA-1 Gene Via Bombardment Approach
}

\author{
Nagm, A.K. ${ }^{1}$, Sherif, H.S ${ }^{1}$, Abdel-Sabour, M.S ${ }^{1}$, El-Akkad, T.A. ${ }^{1}$, Sherif, S.S. ${ }^{2}$ \\ ${ }^{1}$ Genetics and Genetic Engineering Dept., Faculty of Agriculture, Benha University, Egypt \\ ${ }^{2}$ Medicinal and Aromatic Plants Department, Hort. Res. Institute, A.R.C., Egypt \\ Corresponding author: Abeerkamal254@gmail.com
}

\begin{abstract}
The main aim of this study was to introduce HVAl gene into Catharanthus roseus callus by using PDS (Particle delivery system). In vitro seed germination of $C$. roseus was achieved using vigor seeds. The shootlets induction medium was MS containing $2.0 \mathrm{mg} / \mathrm{l}$ benzyl aminopurine $^{-1}$. Somatic embryogenesis was obtained by culturing various parts of explants (stem, root and leaves disc) on MS containing 2, 4-D at $3.0 \mathrm{mg} / \mathrm{l}$ and subcultured on MS medium containing coconut juice 3\%. Genetically transformed C. roseus somatic embryos were obtained after bombardment of embryonic calli, by $p A B 1$ plasmid harboring $H V A-1$ gene, salt resistance, and Bar gene, herbicide resistance, coated gold particles 1.0 micron, 1100 and 1350 Psi with $130 \mathrm{~mm}$ with HAVl gene. The data showed that the transgenic line exhibited different levels of salt tolerance as expressed by the performance of plants dry weight, proline content and drought tolerance test. HVA-1 gene enhanced vinca salt tolerance hence enhancing the production of the important secondary metabolites from transgenic plants. The results of the present study can be seen as a step towards development of salinity tolerant transgenic vinca genotypes.
\end{abstract}

Keywords: HAV1 gene, Catharanthus roseus, genetic transformation, salinity, somatic embryos particle bombardment

\section{Introduction}

The utilization of medicinal plants as a natural source of drugs is being increasingly encouraged (DiCosmo, 1990 and Phillipson, 1990). Consequently, medicinal plants have been targeted for uncontrolled collection and destruction as a result of urbanization, overgrazing, pollution and expansion of cultivated areas (Namedo, 2007). Plant secondary metabolism gives rise to the formation of a vast array of chemically complex compounds, many of which are commercially important.

The low in planta production of these antineoplastic drug molecules vinblastine and vincristine and their inability to be chemically synthesize have amplified their high market demand with exorbitant price and has brought $C$. roseus plant on the center stage of (total indole alkaloids) TIAs pathway metabolic engineering efforts in recent years (Qu et al. 2015; Wang et al. 2016). The multi-step TIAs biosynthetic pathway is highly complex and strictly regulated through developmental, environmental, organo-, and cell-specific controls (StPierre et al. 1999; Van-der Heijden et al. 2004; Rischer et al. 2006 and Verma et al. 2012). Therefore, production of indole alkaloids by $C$. roseus in vitro cultures is still one of the greatest interests and challenges that attract many researchers to explore the technologies to produce higher amount of dimeric antineoplastic drug molecules and their precursors and has developed $C$. roseus as a well-established model system to study for biosynthesis and regulation of secondary metabolites (Zhao and Verpoorte, 2007 and Qu et al. 2015). has developed C. roseus as a well-established model system to study for biosynthesis and regulation of secondary metabolites (Zhao and Verpoorte 2007, and Qu et al. 2015).

$H V A 1$, is a group-3 late embryogenesis abundant (LEA) stress-related protein coding gene from barley (Hordeum vulgare L.), which is specifically expressed in the aleurone layer and the embryos during late seed development (Hong, et al., 1992 and Babu, et. al., 2004).

Expression of the HVAl gene is rapidly induced in young seedling under several stress conditions, such as dehydration, salt, drought and extreme temperatures or by absisic acid (ABA) treatment (Hong, et. al., 1992). The function of HVAl protein in stress protection has been investigated using a transgenic approach in rice (Xu, et. al., 1996), barley (McKersie, et. al., 1996), alfalfa (Siviamani, et. al., 2000) and Oat (Maqbool, et. al., 2002).

Late embryogenesis abundant (LEA) proteins are produced late during embryo development and constitute around $4 \%$ of the total cellular proteins. These proteins are expressed in seeds as well as in drought stressed tissues where they play a major role as cellular protectants.

LEA proteins are also produced in anhydrobiotic plants, animals and microorganisms in which their expression correlates with desiccation tolerance. At least six different groups of LEA proteins have been identified based on their amino acid sequence, mRNA homology and expression pattern (Dure, 1993 and Wise, 2003). Various functions have thus been proposed to LEA proteins where they act as either hydrating buffer (Dure, 1993; Ingram and Bartels, 1996), sequester ions (Dure, 1993), act as chemical chaperones (Close, 1996), help in renaturing cellular 
proteins, and transport of nuclear targeted proteins during stress (Goday, et. al.,1994).

Group 3 LEA proteins have an 11-mer amino acid motif with the consensus sequence TAQAAKEKAGE and encode a 213 amino acids protein (Dure, 2001). In $H V A 1$, this motif is repeated as many as 9 times forming an alpha helical dimer suitable for accommodating positively and negatively charged ions thus providing a putative function of group 3 LEA proteins in ion sequestration. Overexpression of HVAl to produce transgenic plants is one of the approaches followed to understand its role in stress protection. This gene has been successfully introduced into rice (Xu, et. al., 1996 and Rohila, et. al., 2002) and has been shown to confer tolerance against both salt and water deficit conditions.

Vinca, Catharanthus roseus (L.) G. Don. (Apocyanaceae), is one of the important medicinal plants especially in Egypt, It has a good antioxidant potential.

To date, genetic transformation of $C$. roseus has been mostly confined to hairy roots and suspension cells. Agrobacterium rhizogenes-mediated transformation involving productions of hairy (transgenic) roots in $C$. roseus had been reported (Magnotta, et. al., 2007; Choi, et al., 2007. However, the phenotypes of transgenic $C$. roseus plants transformed by A. rhizogenes are abnormal, such as shortened internodes, wrinkled leaves and abundant root mass Choi, et al., 2007. Thus, this kind of transgenic $C$. roseus plants is not suitable for the production of TIAs. Transgenic $C$. roseus cell suspension cultures transformed by either Agrobacterium infection or by particle bombardment had been established and studied intensively ((Magnotta, et. al., 2007; Van-der Fits, et al., 1997 and Canel, et al., 1998). But these transgenic cells lines do not produce alkaloids in a stable manner and their ability to accumulate TIAs is gradually declined by long-term subculture (Whitmer, et al., 2003). Recently A. tumefaciens-mediated transformation was employed in C. roseus, the transgenic callus and plants were obtained respectively (Srivastava, et al., 2009 and Verma, et. al., 2011). However, these transformation systems were not confirmed with other biochemical assays such as southern blot and highperformance liquid chromatography (HPLC). To address these issues, in the present study we developed an A. tumfaciens mediated transformation and regeneration system of $C$. roseus (Srivastava, $\boldsymbol{e t}$ al., 2009). The stable regeneration plants were successfully acquired. To demonstrate this transformation system, HVAl, an essential gene in salinity was overexpressed and the accumulation of vincristine was analyzed using HPLC in transformants.

Also, a recent study was conducted on the ability to produce transgenic plants from somatic embryos of C. roseus, which are capable of growing at high concentrations of salinity with an enhanced effect on the contents of vincristine and vinblastine.

\section{Materials and Methods}

\section{In vitro culture}

\section{a. Seeds disinfecting}

Seeds of Vinca, Catharanthus roseus (L.) G. Don. (Apocyanaceae), were purchased from the Ornamental Dept., Faculty of Agriculture, Cairo University, Egypt. The seeds were divided into groups each one contains more than 50 seeds. The seeds were washed in soap water using septol soap for $30 \mathrm{~min}$ and rinsed with running tap water for one hour. The seeds were transferred under laminar flow cabinet and washed three times with sterile distilled water. Seeds were surface sterilized by dipping in $70 \%$ ethanol for $1 \mathrm{~min}$, followed by immersion in 5, 10 and $20 \%$ sodium hypochlorite (commercial bleach is mainly hypochlorite) for 20,10 and $5 \mathrm{~min}$, also merrcruric chloride used at $0.1,0.2$ and $0.3 \%$ for the same time plus tween-20 (2 drops / $100 \mathrm{ml}$ ) as emulsifier for 15 min with agitation under aseptic conditions and then rinsed in sterile distilled water for three times.

\section{b. Shootlets production}

The sterilized seeds were germinated on MS media (Murashige and Skoog, 1962) free hormone and the seedlings were transferred on proliferation MS medium containing BAP at 1.0, 2.0 and $3.0 \mathrm{mg} / \mathrm{l}$ and kinitine at $0.1,0.2$ and $0.3 \mathrm{mg} / \mathrm{l}$ with their interactions for shootlets production.

\section{c. Rhizogenic shootlets production}

The successful shootlets production from proliferation were cultured on MS medium containing BAP or kin at $0.25,0.50$ and $0.75 \mathrm{mg} / \mathrm{l}$ and interactions with $0.25,0.50$ and $0.75 \mathrm{mg} / \mathrm{l} \mathrm{IBA}$ for two subcultures (4 weeks for each)

\section{d. Callus and somatic embryos production}

Callus was induced from three parts of explants leaf discs, stem and root that cultured on MS medium containing 2,4-D and/or NAA at 1.0, 2.0 and $3.0 \mathrm{mg} / \mathrm{l}$ and their interaction with control (MS free) for one week on darkness (Choudhury and Gupta, 1995).

\section{e.Somatic embryo regeneration}

The callus formed from above treatments were cultured on MS medium containing some elicitors to induce shoots from somatic embryos (Coconut water at 10,20 and $30 \mathrm{ml} / 1, \mathrm{AgNO}_{3}$ at $0.1,0.2$ and $0.3 \mathrm{mg} / \mathrm{l}$ and Malt extract at 10, 20 and $30 \mathrm{ml} / \mathrm{l}$ ).

\section{Plant Expression Vector}

\section{a. Source and characterization of the} expression vector

The plant expression vector pAB1, (kindly provided by Prof. Dr. Ahmed Bahi-eldin, Faculty of Agriculture, Ain Shams University and AGERI), was used in this study for the transformation of Vinca calli. The plasmid contains the barley HVAl gene driven by the maize ubil promoter region (including the first 
exon and intron) and terminated by the Nos gene $3^{\prime}$ non-translated region (figure 1). It also contains the bar gene (under the control of the $35 \mathrm{~S}$ promoter and Nos terminator) which has been used as a selective marker. The bar gene encodes the enzyme phosphinothricin acetyl transferase (PAT) which inactivates phosphinothricin, the active ingredient of the herbicide bialaphos. (Klein, et al,. 1988).

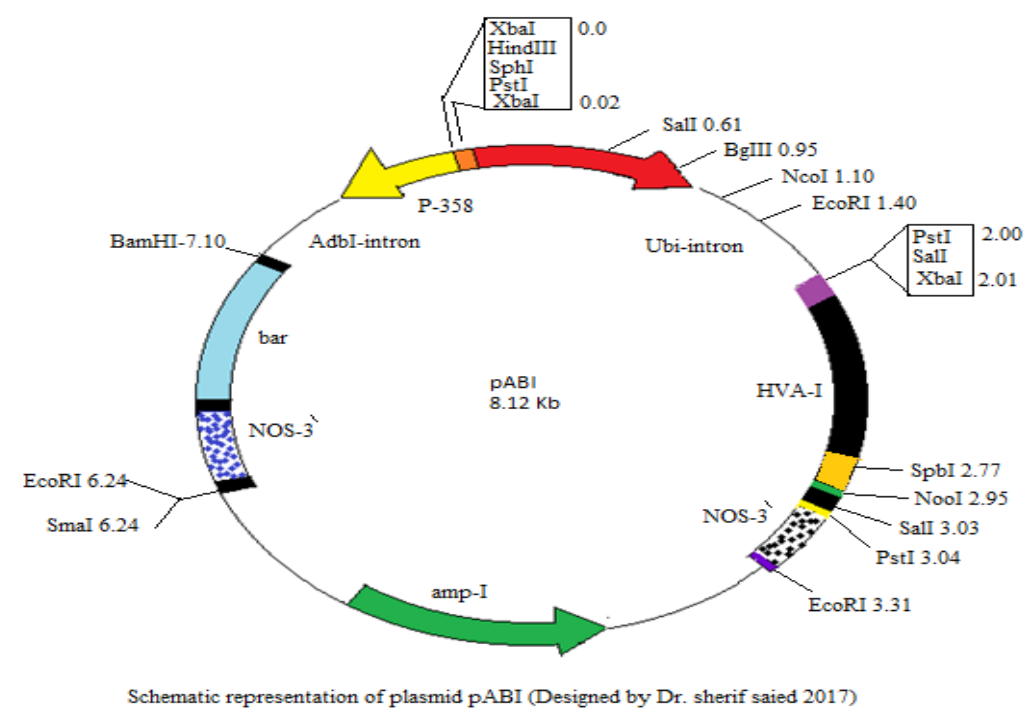

Fig. 1. The plant expression vector, pAB1, map harboring the barley HVAl gene as well as bar gene

\section{b. Somatic embryos preparation}

As far as the biolistic approach was concerned, a mean of 3-4 $(\approx 1.0 \mathrm{gm})$ vinca somatic embryos per 6 $\mathrm{cm}$ Petri dish (covering an approximate area of 9-10 $\mathrm{cm} 2$ ) were placed on the osmo-pressure medium MS medium containing $2.0 \mathrm{mg} \mathrm{l}^{-1} 2,4-\mathrm{D}$ and $3 \mathrm{mg} \mathrm{l}-1$ NAA

(Yadav and Sticklen, 1995), and supplemented with $4 \%$ Mannitol. The somatic embryos explants were kept on the above medium for 5 hour prior to bombardment.

\section{c. Bombardment conditions}

Transformation has been carried out using the biolistic particle acceleration device (PDS 1000/He, Bio-Rad). For micro-projectile bombardment, plasmid DNA $(1 \mu \mathrm{g} / \mu \mathrm{l})$ was precipitated onto gold particles $(1.0 \mu \mathrm{m}$ in diameter) following the procedure described in the Bio-Rad instruction Manual. Each plate of vinca calli was bombarded twice at a rupture pressure of 1100 and 1350 psi with $5 \mu 1$ of particle suspension mixture per bombardment. (Rafael, et al., 1999)

d. Selection and recovery of transformed calli

Bombarded calli were sub-cultured on the callus induction medium for one week after bombardment for callus recovery. Then, selection of transformed culls was carried out by transferring the transformed calli to the callus induction medium containing 1.5 $\mathrm{mg} / \mathrm{l}$ bialaphos, for herbicide resistance selection, for 2 weeks. The calli were then, sub-cultured on fresh selective media containing $3 \mathrm{mg} / \mathrm{l}$ bialaphos, with continuous subcultures every 2 weeks. All cultures were incubated at $28^{\circ} \mathrm{C}$ in a dark growth chamber (Rafael, et al., 1999).

\section{e. Regeneration and recovery of transformed plants}

The recent calli, which grew uniformly on the selection media, were transferred to regeneration medium supplemented with $30 \mathrm{ml} / \mathrm{l}$ coconut juice. Somatic embryogenic calli capable of developing into green shoots within 2-4 weeks were classified as putative transformants. The selected plantlets were transferred into multiplication media and then transferred to selective media to evaluate the ability of tolerant growth under salinity conditions.

\section{Evaluation of transformed plants}

a. Polymerase chain reaction analysis PCR

Genomic DNA was isolated from leaves tissue of each putatively transformed plant as well as from nontransformed plants (control) using DNeasy ${ }^{\circledR}$ Plant mini Kit. Two sets of primers were used to detect the presence of bar and $H V A l$ genes using PCR test. The sequence of the specific primers for the HVAlgene were HVAla (5'- GGA GAT CTA ACA ATG GCC TCC AAC CAG AAC CAG GGG -3') and $H V A l b$ (5'- GGG ATA TCT AGT GAT TCC TGG TGGTGGTGG TG -3 '). The PCR reaction was carried out in a $25 \mu 1$ reaction volume containing $25 \mathrm{ng}$ genomic DNA, 20 pmole $/ \mathrm{ml}$ primers, $200 \mu \mathrm{M}$ each of dATP, dCTP, dGTP and DTTP, $50 \mu \mathrm{M} \mathrm{KCl}, 10$ mMTris- $\mathrm{HCl}, 0.2 \mathrm{mM} \mathrm{MgCl} 2$ and 0.2 unit of Taq polymerase (Chiu, et al., 1996).

The PCR thermocycle profile, for the amplification of the studied genes, was; an initial denaturation cycle at $94^{\circ} \mathrm{C}$ for $5 \mathrm{~min}$., followed by 35 cycles of $94^{\circ} \mathrm{C}(1 \mathrm{~min}), 57^{\circ} \mathrm{C}(2 \mathrm{~min}), 72^{\circ} \mathrm{C}(2 \mathrm{~min})$ and a terminal extension cycle at $72^{\circ} \mathrm{C}(7 \mathrm{~min})$ for $\mathrm{bar}$ gene. While, for the HVAl gene the thermocycle 
profile was $94^{\circ} \mathrm{C}(4 \mathrm{~min})$, followed by 35 cycles of $94^{\circ} \mathrm{C}(1 \mathrm{~min}), 59^{\circ} \mathrm{C}(40 \mathrm{sec}), 72^{\circ} \mathrm{C}(1 \mathrm{~min})$ and a final cycle at $72^{\circ} \mathrm{C}(7 \mathrm{~min})$. The $\mathrm{PCR}$ products were determined by electrophoresis on $1.2 \%$ agarose gel. (Chiu, et al., 1996).

\section{b. Salt tolerance}

Two lines of Vinca (transformed and nontransformed plants) were used as plant materials to evaluate the effect of the Hval gene on salinity tolerance in vinca. The explants were subjected to salt stress by the addition of 0, 1000, 3000 and 5000 ppm $\mathrm{NaCl}: \mathrm{CaCl}_{2}$ to $\mathrm{MS}$ culture medium. Survival was measured after four weeks for two subcultures from starting salt treatment also, shoot number, shootlet length and leaves number. Data obtained were statistically analyzed and mean comparisons were based on LSD at 5\% tests by using the software according to Maxwell and Delaney (1990).

\section{c.Vincristine level}

Extractions: In vitro samples ranged $(0.5-1.5 \mathrm{~g})$ were extracted with $50 \mathrm{ml} \mathrm{MeOH}$ for $24 \mathrm{~h}$ by cold maceration. The filtered extracts were dried and residues were dissolved in $3 \mathrm{ml}$ of $1 \mathrm{~N} \mathrm{H}_{2} \mathrm{SO}_{4} \mathrm{pH}$ of each of the acidic extracts were adjusted to 9.0 with $20 \% \mathrm{NH}_{4} \mathrm{OH}$ soln, and shaken with $5 \mathrm{ml} \mathrm{CHCl}_{3}$ layer was sep. out and dried.

HPLC determination: The final residues were dissolved in $1 \mathrm{ml}$ of a 1: 4 mixt. of $0.5 \mathrm{~N} \mathrm{H}_{2} \mathrm{SO}_{4}$ and HPLC mobile phase, i.e. $\mathrm{MeOH}-\mathrm{Me}_{2} \mathrm{CN}-2.5 \mathrm{mM} \mathrm{KPi}$ buffer (pH 7.0) (48:20:32). The external standard used for quantitative analysis (vinblastine sulphate) was also treated in the same way to eliminate any error in extraction. For HPLC analysis, a Merck LiChroCART $\mathrm{C}_{18}$ Column (125 x 4mm, $\left.5 \mu \mathrm{m}\right)$ and the solvent system were used at a constant flow rate of 1

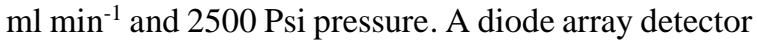
was employed for detection the peaks, set at wave length of $255 \mathrm{~nm}$ and band width of 5 according to Aniruddha and Srivatava (1997).

\section{d. Proline estimation}

For determination of proline, the method of Bates et al. (1973) was used. Fresh leaves $(500 \mathrm{mg})$ from each of the three replicates for each treatment were homogenized in $10 \mathrm{ml}$ of $3 \%$ sulphosalicylic acid. This extract was used for the estimation of proline spectrophotometrically at $520 \mathrm{~nm}$.

\section{Statistical analysis}

A simple experiment passed on a completely randomized design (CRD) was used in this study. Number of shoots/callus, number of regenerated calli (out of 25) and number of rooted calli (out of 25) were statistically analyzed using the analysis of variance (ANOVA) as outlined by (Gomez and Gomez, 1984) using MSTATC program. The differences between means were compared using Duncan multiple test (Duncan, 1955).

\section{Results and Discussions}

\section{In vitro culture}

\section{a. Micropropagation}

Data in Fig. (2) showed the effect off some commercial bleach (Sodium hypochlorite) and mercuric chloride on decontamination rate of Catharanthus roseus seeds. Both of sodium hypochlorite $10 \%(\mathrm{v} / \mathrm{v})$ and $\mathrm{HgCl}_{2}$ at $0.2 \%(\mathrm{w} / \mathrm{v})$ for $10 \mathrm{~min}$ gave the highest percentage $(81 \%)$ of decontamination percent. In this concern, Fernandez et al. (1989) Stated that seeds of Catharanthus roseus (L.) G. Don. (approximately $0.5 \mathrm{~g}$ batches) were soaked for $30 \mathrm{sec}$ in $70 \%$ ethanol and rinsed with three changes of sterile water. After sterilization, seeds were imbibed in sterile water for $24 \mathrm{~h}$ at room temperature. Also, Bunnag et al. (2006) found that the best sterilization condition was achieved by immersing the explant in $0.01 \%(\mathrm{w} / \mathrm{v})$ aqueous solution of mercuric chloride and then rinsing 3 times in sterile distilled water. This method is the most effective protocol for reducing the percentage of contamination $(12 \%)$ while retaining highest survival percentage $(88 \%)$.

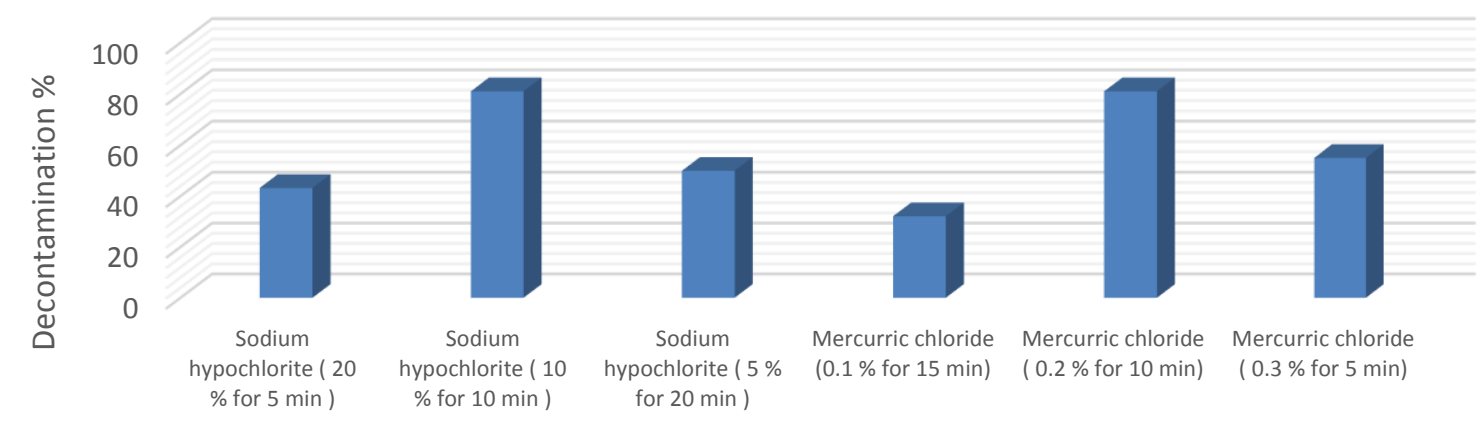

Fig. 2 effect of some disinfecting treatments on decontamination rate of $C$. rouses seeds 
According to the data in Fig. 3, the MS media containing $3 \mathrm{mg} / \mathrm{l} \mathrm{BAP}$ (M3) gave the best results for growth explants while it increased the mean of shoot number to the maximum level 7.44 shootlet/explants followed by increasing the average of shootlets length for each explants to $10.58 \mathrm{~cm} /$ shootlets that gave the highest number of leaves per shootlets (16.61 leaves/shootlets).

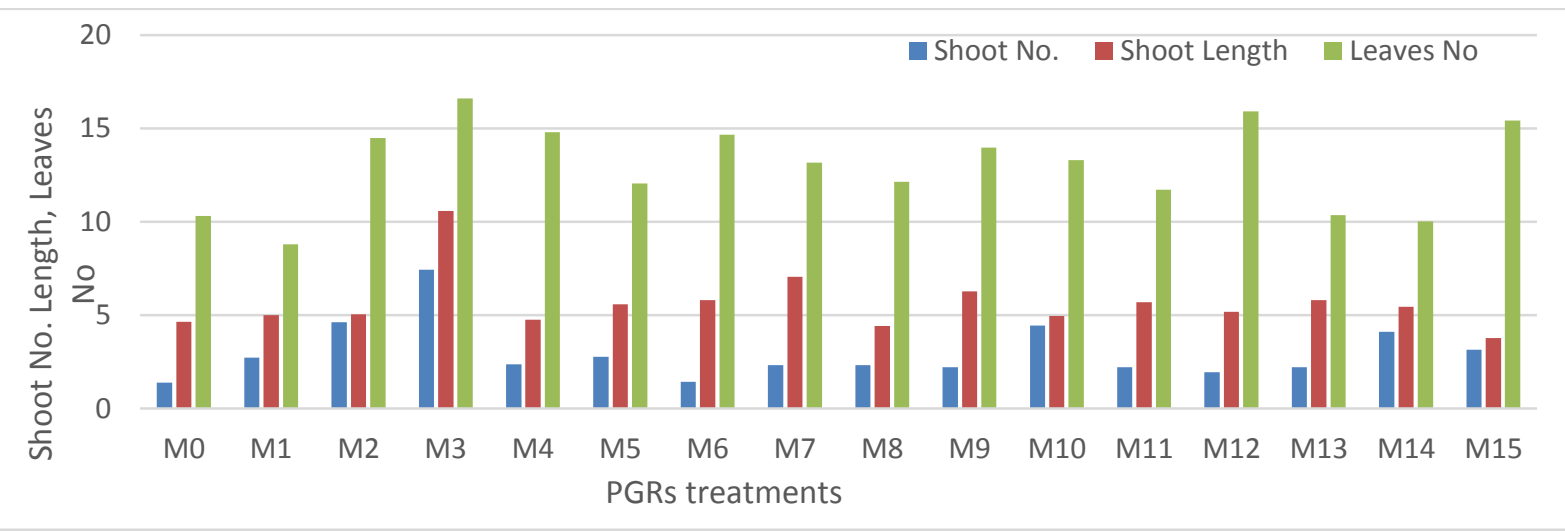

Fig.3. Effect of BAP and Kinetin and their interactions on growth characters of C. rouses. Where, M0: control; M1, 2, 3 BAP 1, 2 and $3 \mathrm{mg} / \mathrm{l}$; M4, 5, 6 Kin $0.1,0.2$ and $0.3 \mathrm{mg} / 1$; M7 to M15 their interactions

In this concern, Mondal et al. (2002) found that aseptic culture of nodal segments of Camellia sinensis (L.) O. kuutze were initiated on half strength MS medium supplemented with $8.88 \mu \mathrm{M}$ BAP in combination with $0.98 \mu \mathrm{M}$ IBA. After 30 days, the sprouted buds of the nodal segments were transferred to hormone-free MS medium for further multiplication, so as to allow the shoots to attain a height of $3.0 \mathrm{~cm}$. Also, Bhatia and Ashwath (2008) found that shoot length of Lycopersicon esculrntum Mill. Cv. Red Coat in the control was similar to that of the treatments containing 1 or $5 \mathrm{mg} / \mathrm{l}$ activated charcoal. However, at $10 \mathrm{mg} / \mathrm{l}$ shoot height increased to $11.3 \mathrm{~mm}$. Moreover, Naghmouchi et al. (2008) reported that shoot elongation of Ceratonia siliqua depends on the medium used. The addition of GA3, IBA and BAP ameliorates bud sprouting and shoot elongation. The best elongation was shown on media with BAP. Shoots obtained on free BAP medium presented short internodes and quickly lost their ability to elongate. The data remined on the rooting percentage (Fig. 4) during second subculture with active charcoal were significantly increased to the highest value $100 \%$ for explant treated with all treatments except with those treated with BAP at 0.25 $\mathrm{mg} / \mathrm{l}$ plus IBA 0.25 or $0.75 \mathrm{mg} / \mathrm{l}$; BAP at $0.5 \mathrm{mg} / \mathrm{l}$ plus IBA $0.5 \mathrm{mg} / \mathrm{l}$ and kin plus IBA at 0.25 or $0.5 \mathrm{mg} / \mathrm{l}$ as well as control. Moreover, applying BAP $0.75+$ IBA $0.75 \mathrm{mg} / \mathrm{l}$; Kin $0.25+$ IBA $0.5 \mathrm{mg} / \mathrm{l}$ and BAP $0.5+$ IBA $0.75 \mathrm{mg} / \mathrm{l}$ only gave the highest percentage of rooting for explants cultured on MS medium without adding activated charcoal. These data are in agreement with those found by Diab and Mohamed (2008) who reported that MS medium full strength supplemented with $8.0 \mathrm{mg} / \mathrm{l}$ IBA gave the highest rooting percentage $(70 \%)$ compared to other treatments using the same concentration of IBA $(20 \%$ and $15 \%$ ) with the half and quarter strength of MS medium. These results disagreed with the results of Kashmauika and Niranjini (1995) who reported that shoots developed from axillary buds could be rooted on MS media at half strength supplemented with 5.0 $\mathrm{mg} / \mathrm{l}$ IBA for Bambusa vulgaris Also, disagreed with the findings of Saxena and Dhawan (1999) who recommended that, half strength MS medium supplemented with $4 \mathrm{mg} / \mathrm{l}$ NAA was required for rooting of Dendrocalamus strictus.

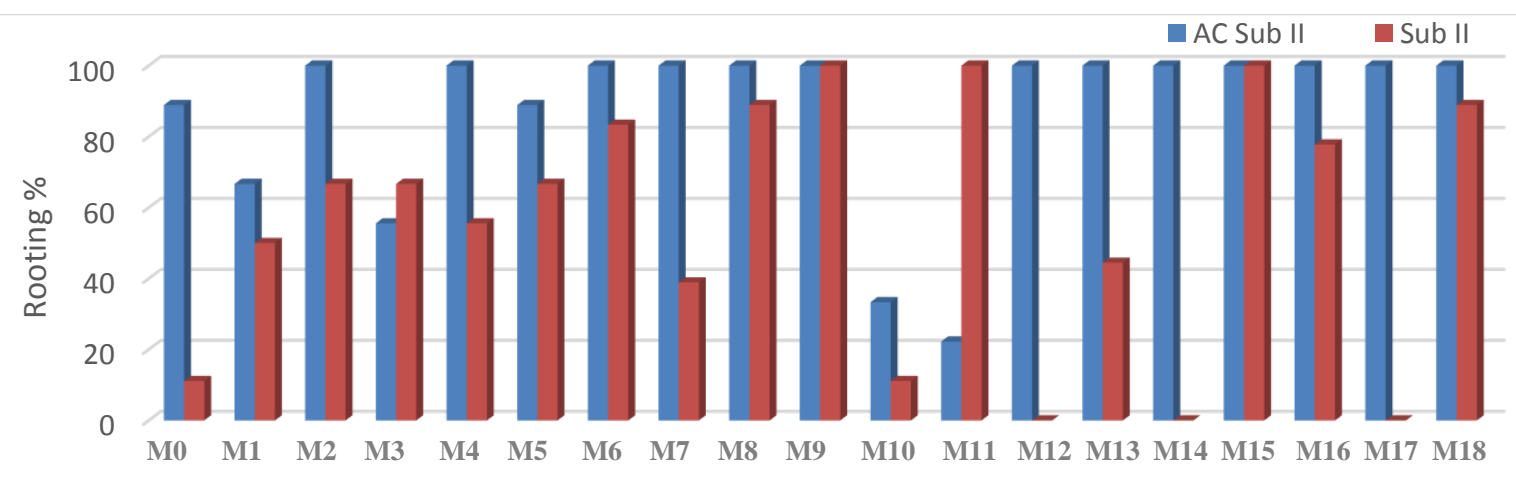

Rooting treatments

M0: control; M1-M9 IBA at 0.25, 0.5, 0.75 interaction BAP at 0.25, 0.5 and 0.75; M10 - M18 IBA interaction Kin at 0.25, 0.5 and 0.75

Fig. 4. Effect of BAP, Kin and IBA on rhizogensis of C. rouses explants 


\section{b. Callus and somatic embryos induction}

At the end of micropropagation stage three parts of explant were cultured on MS media supplemented with 2,4-D and NAA at three concentrations $0.5,1.0$ and $1.5 \mathrm{mg} / \mathrm{l}$ for each and their interactions were applied on growth medium for induction of callus. Data in Fig. 5 showed that the stem tissues have more ability to initiate callus than leaves and roots whereas, it gave the highest percentage of callus for all treatments ranged from 77.8 to $100 \%$ of callus induction except with control. The second organ can be dedifferentiated to callus was leaves which was record $100 \%$ of callusing for many treatments. Although stem gave the highest level of callus, but the active ingredient as well as somatic embryos formation and regeneration ability was observed for the cells produced from leaves according to the data in Table (1).

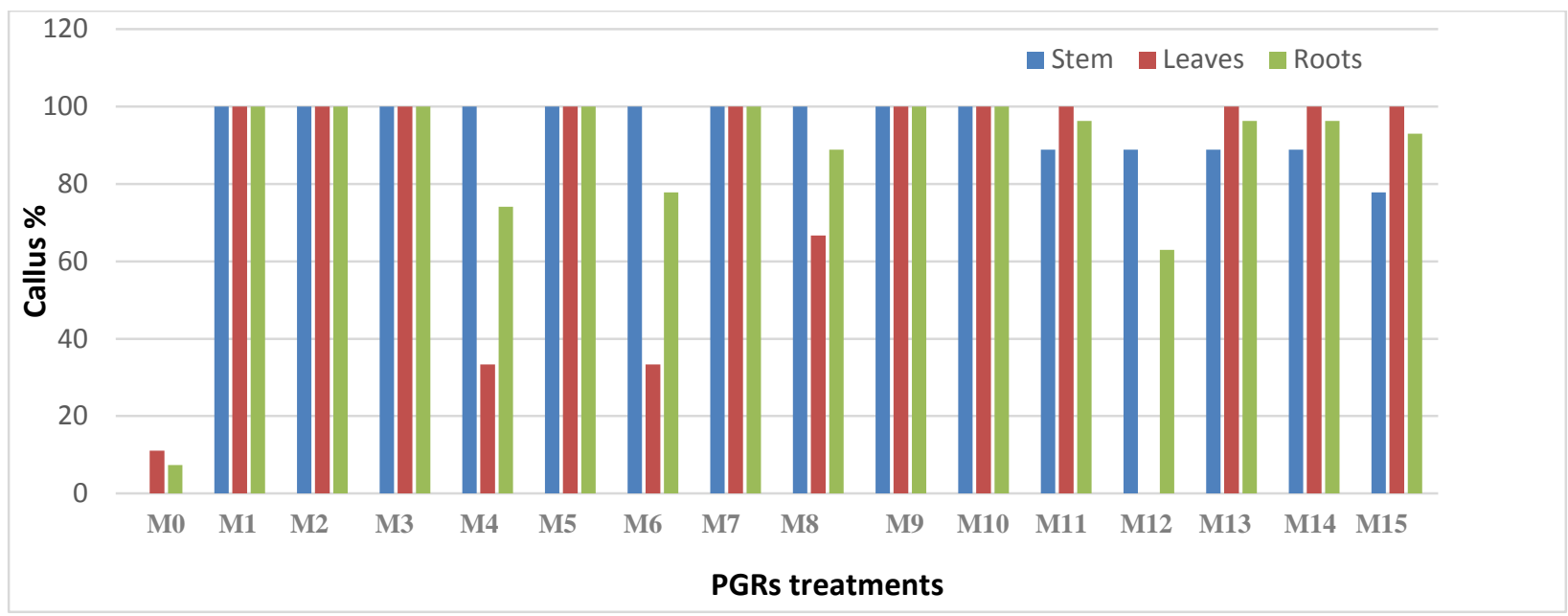

M0: control; M1-M3 2, 4-D at 0.5, 1.0, 1.5; M4-M6 NAA at 0.5, 1.0 and 1.5; M7 - M15 2, 4-D interaction NAA at 0.5, 1.0 and 1.5

Fig. 5. Effect of plant growth regulators and part of explants on callus formation of $C$. rouses

The data in Table (1) showed three different approaches were employed to increase the formation of embryogenic calli (EC). The used approaches were aimed for choosing the best type and concentration of natural extract, thereby inducing somatic embryo and subsequent plant regeneration. The data in table (1) and Fig 5. showed that the 30-day-old callus were cultured on MS medium with different concentrations of $\mathrm{AgNO}_{3}$, Coconut milk, and malt extract. The growth rate of callus (both of non-embryogenic calli and embryogenic calli) as well as percentage of EC were determined after 4 weeks culture. It was observed that, during proliferation, the somatic embryos emerged from callus surface. In addition, EC grew more slowly than non-EC. MS medium with 30 $\mathrm{ml} / \mathrm{l}$ coconut milk and $20 \mathrm{mg} \mathrm{L}-1$ was the most effective medium in inducing and proliferating somatic embryos $85 \%$ callus with 8.7 SE (average of SE/explant) from embryonic calli grown from leaves. Although somatic embryos on MS medium with coconut $30 \mathrm{ml} / \mathrm{l}$ were faster elongated than those on MS medium with malt extract and $\mathrm{AgNO}_{3}$, the quantity of somatic embryos was less. for control treatment, the frequency of EC from root and stem callus continuously subculture on MS medium containing AgNO3 and Malt extract was probably underestimated because of overgrowth of non-EC. Accordingly, coconut extract can increase the quantity of somatic embryos, but the effects of the source of callus on somatic embryo germination and subsequent plantlet formation should be regarded.
The frequency of callus formation from leaves on MS medium containing coconut extract at $30 \mathrm{ml} / \mathrm{l}$ gave the highest level of callus $85.66 \%$ compared with control $(22.22 \%)$ while, malt extract recorded the lowest level of callus $18.22 \%$ (Table 1). On the other hand, the callus formed from leaves gave the highest number of somatic embryos 8.7 SE/explant following by $6.3 \mathrm{SE} /$ explant from callus cultured on MS medium containing $20 \mathrm{ml} / \mathrm{l}$ coconut milk. Moreover, the somatic embryos reached to the highest percentage of regeneration $66.66 \%$. In this concern, in a previous studies the researchers have used various types of explants viz. cotyledon, hypocotyl, pedicel, peduncle, leaf, stem sections and inflorescence for organogenesis. The type of the used explant not only determines the proportion of explants, which show organogenesis, but also the number of shoots produced per explant. While, Duzyaman et al. (1994) found that the degree of shoot regeneration was in the order of leaves $\geq$ cotyledons $\geq$ hypocotyls, and all cultivars responded similarly. Duzyaman et al. (1994) reported differential regeneration frequency of various explants in the order of hypocotyl, cotyledon , leaf. Preferential regeneration was also demonstrated from hypocotyl explants better than from cotyledon explants (Gunay and Rao, 1980 and AjenifujahSolebo et al., 2013). In contrast to these findings, Schutze and Wieczorrek (1987) reported that in vitro shoot production from cotyledon explants was better than that from hypocotyl explants. 
Table (1) Effect of coconut milk, Malt extract and AgNO3 on somatic embryos formation and regeneration percentage of C. roseus

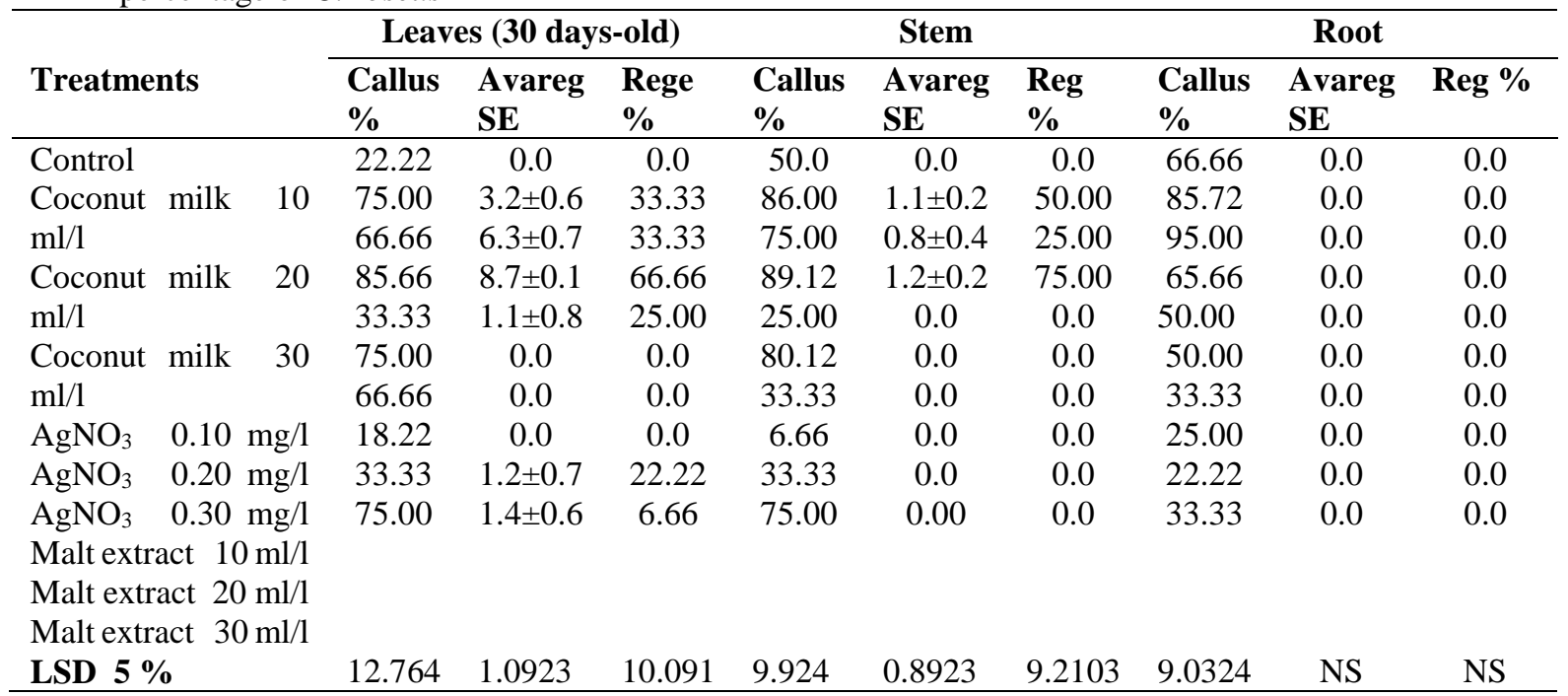

Data represent mean \pm standard deviation for somatic embryos.

Each column represent mean of treatments and comparing between means by Duncan multiple test at $5 \%$.

On the other hand, the effect of coconut milk was discussed by many researchers who reported that, using coconut water elsewhere showed that coconut water is rich in lysine, cystine, histidine, methionine and other essential amino acids (Thio, 1982), and has a high concentration of vitamins and minerals together with potassium, calcium and magnesium (Gopikrishna et al., 2008) as well as contains a lot of sugars.

1. Optimization of transformation conditions for $C$. roseus
For improvement abiotic stress tolerance including salinity in Catharanthus roseus, the HVA-1 gene, which has a role in defense against oxidative stress (Quan, et. al., 2012), was previously synthesized and cloned in the plant expression vector $p A B 1$. This plasmid was used for $C$. roseus transformation in the present study. In this study, we reported for the first time the development of transformed Vinca plants harboring HVA-1 gene. Embryogenic calli were produced from Vinca leaves callus (Figure 6, A. B.C).
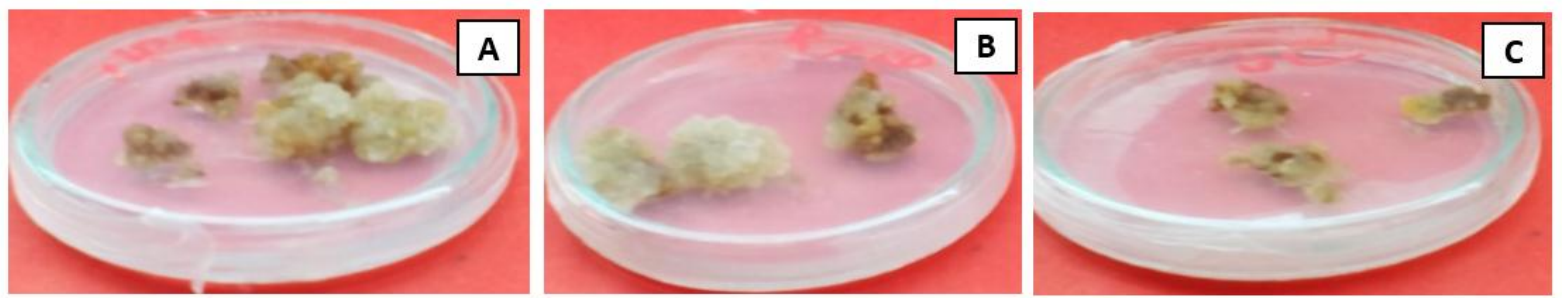

Fig. (6) Three ages of embryonic calli (A) Before shooting (B) after one week of shooting and (C) after four weeks cultured on osmotic MS medium

Three ages of embryonic calli were used in the transformation experiments using BiolisticTM device. The bombarded calli grew well on the MS callus induction medium at $25^{\circ} \mathrm{C}$ in complete darkness for the first week after bombardment for callus recovery (Figure 6B). These calli proliferated rapidly and displayed somatic embryos in form of fast growing with granular sectors. There were also some nonproliferating and partially necrotic mother calli (brown sectors) which were removed at each subculture during selection steps. Four weeks after transferred onto the regeneration medium containing $30 \mathrm{ml} / \mathrm{L}$ of coconut milk and incubated under fluorescent light condition of $16 \mathrm{hr}$ light/ $8 \mathrm{hr}$ dark and $25^{\circ} \mathrm{C}$ growth room, somatic embryos quickly regenerated into shootlets with small roots. Four weeks after they were transferred onto root proliferating MS medium containing $1 \mathrm{mg} / \mathrm{L}$ of IBA, plantlets developed large primary and secondary roots. The explants after growing and regeneration was transferred on MS medium containing salinity treatments.

In this concern, De Guglielmo-Cróquer, et. al., (2010) worked on transformation of coffee plantlets with the $B$. thuringiensis (crylac) gene without reporter (gus A) gene is feasible by biolistic gun. Kanamycin a widely used marker for plant transformation that can be phytotoxic and inhibit untransformed tissues, and the nptII gene can be used as a selectable marker in plants. Also, the 
development of transgenic plants of two common bean varieties that are able to grow in the presence of high concentrations of kanamycin and mannitol, and that express the gene product required, for resistance to the drug and for tolerance to drought stress without reporter gus A gene were reported by Eissa, et al., 2013a. The selectable marker $n p t I I$ gene encodes the protein product phosphorrylates and inactivates kanamycin, and renders the drug nontoxic to plant cells as reported by Eissa (2013a and b). The bombarded cotyledonary node explants were incubated for 24 hours without kanamycin selection to allow expression of the resistance gene.

Cotyledonary nodes were cultured on regeneration media with 50 and $75 \mathrm{mg} / \mathrm{l}$ kanamycin as selection agent for regeneration. Stable transformants were then selected by culturing the explants on medium containing $100 \mathrm{mg} / \mathrm{l}$ kanamycin. Results showed that kanamycin at a concentration of $100 \mathrm{mg} / \mathrm{l}$, totally suppressed the growth of the cotyledonary node tissues as reported by Eissa (2013b). Following several sub cultures on MS medium containing kanamycin and mannitol, most of the shoots obtained from biolistic gun bombarded turned yellow, browned and died. The percentage of co-transformed cotyledonary node tissues by the coated plasmids DNA bombarded with biolistic gun, cultured on double selective MS regeneration medium containing $100 \mathrm{mg} / \mathrm{l} \mathrm{kanamycin}$ and $1.2 \mathrm{M} / \mathrm{l}$ mannitol, as well as supplemented with $1 \mathrm{mg} / \mathrm{l} \mathrm{BA}$ and $0.1 \mathrm{mg} / \mathrm{l} \mathrm{NAA}$ was $7.6 \%$ and $8.4 \%$ for Fönix and Maxidor varieties, respectively.

\section{a. Confirmation of the integration of $\mathrm{HVAI}$} transgenes via PCR

The PCR results confirmed the integration of HVAl in the DNA of the transformed explants (Figure 7). Furthermore, the PCR results confirmed the cointegration of $H V A l$ genes in transformed explants progenies at $60 \%$ for two subcultures. The $60 \%$ cointegration of $H V A l$ genes in transgenic plants is due to the transcriptional linking of the HVAl gene cassettes in the same construct (Figure 7a).
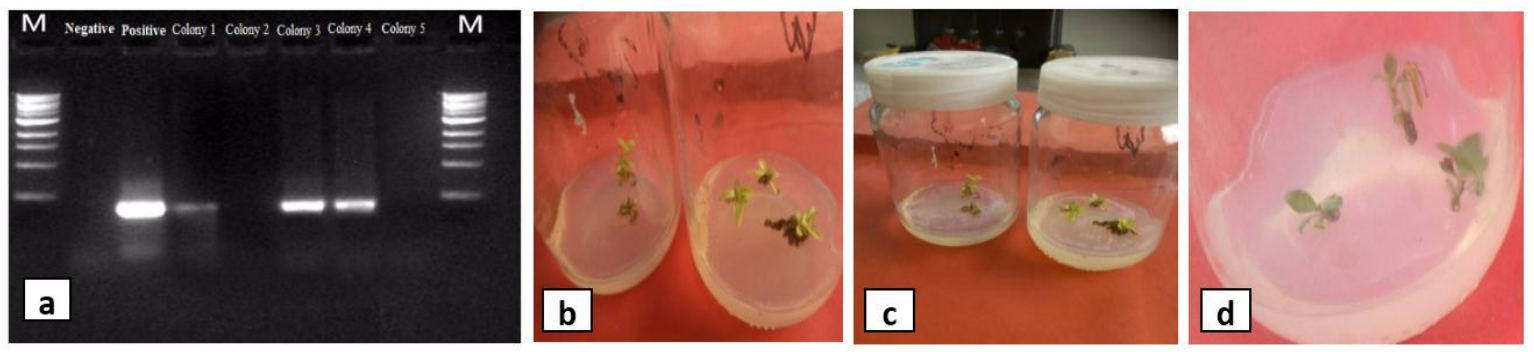

Fig. (7)(a) PCR analysis of transgenic explants by biolistic gun (b, c and d) regeneration in transformed embryonic calli after 4 weeks

Similar observations were reported by Maqbool $\boldsymbol{e t}$ al., (2002), Oraby et al., (2009) and Kwapata et al., (2009) who confirmed stable $100 \%$ co-integration of two linked genes in the subsequent transformed progenies of sorghum and dry bean, respectively. The Transformed explants and the non-transformed explants showed normal development up to one week after being exposed to 1000 ppm $\mathrm{NaCl}: \mathrm{CaCl}_{2}$, but non-transformed plant leaves started showing major injury symptom after being treated with initial $\mathrm{NaCl}$ : $\mathrm{CaCl}_{2}$ concentration of $3000 \mathrm{ppm}$. After increasing the $\mathrm{NaCl}: \mathrm{CaCl}_{2}$ concentration to $5000 \mathrm{ppm}$, the nontransformed plants were severely affected as compared to those treated with $1000 \mathrm{ppm}$.

Table 2. The effect of salinity treatments on some growth characters of transformed and non-transformed explants

\begin{tabular}{|c|c|c|c|c|c|c|}
\hline \multicolumn{7}{|c|}{ Transformed explants } \\
\hline Salt conc. $1 \mathrm{NaCl}: 1 \mathbf{C a C l}_{2}$ & Survival \% & Shoot L cm & Shoot N & Leaves No & Proline & Necrosis\% \\
\hline 0.0 ppm NaCl: $\mathrm{CaCl}_{2}$ & 100.0 & 4.38 & 3.3 & 7.3 & 2.66 & 0.0 \\
\hline 1000 ppm NaCl: $\mathrm{CaCl}_{2}$ & 89.60 & 3.71 & 2.12 & 6.36 & 9.71 & 0.0 \\
\hline 3000 ppm NaCl: $\mathrm{CaCl}_{2}$ & 80.23 & 3.02 & 4.2 & 5.71 & 9.19 & 20.0 \\
\hline 5000 ppm NaCl: $\mathrm{CaCl}_{2}$ & 79.25 & 3.00 & 3.5 & 5.01 & 8.23 & 22.2 \\
\hline LSD $5 \%$ & 9.038 & 0.0382 & 0.620 & 1.021 & 0.7655 & 2.019 \\
\hline \multicolumn{7}{|c|}{ Non-transformed explants } \\
\hline 0.0 $\quad$ ppm $\mathrm{NaCl}: \mathrm{CaCl}_{2}$ & 100.0 & 3.52 & 4.11 & 6.33 & 2.66 & 0.00 \\
\hline 1000 ppm NaCl: $\mathrm{CaCl}_{2}$ & 70.25 & 2.76 & 3.12 & 5.25 & 9.99 & 35.00 \\
\hline 3000 ppm NaCl: $\mathrm{CaCl}_{2}$ & 0.00 & 0.00 & 0.00 & 0.00 & 0.00 & 75.00 \\
\hline 5000 ppm NaCl: $\mathrm{CaCl}_{2}$ & 0.00 & 0.00 & 0.00 & 0.00 & 0.00 & 100.0 \\
\hline LSD 5\% & 6.032 & 0.561 & 0.213 & 0.122 & 0.291 & 10.34 \\
\hline
\end{tabular}

Each column represent mean of treatments and comparing between means by Duncan multiple test at 5\%.

At 5000 ppm NaCl: $\mathrm{CaCl}_{2}$ concentration, both transformed and control plants showed severe leaf injury after one week of salt treatment. 
Data in Figure 8 displayed the results of the effect of different salt concentrations on transformed versus non-transformed (control) plants on shoot and levees number, survival and necrosis percentage. Figure 8 showed symptoms of salinity tolerance of the transformed plants. Table 2 showed that the reduction in survival percentage from $100 \%$ of both transformed and control plants on MS salt free medium to 89.60 and $70.25 \%$ when exposed to 1000 ppm NaCl: $\mathrm{CaCl}_{2}$, respectively However, at 3000 ppm, percentage of survival reduction in control (non transformed) and transformed plants were $0.0 \%$ and $80.23 \%$, respectively, wherase the non-transformed plants were dead after 1000 ppm selection agent. Also, the shoot number and shoot length were decreased by increase salt concentrations in transformed plants $4.36,3.71,3.02$ and $3.0 \mathrm{~cm}$ after increasing salts from 0.0 to $5000 \mathrm{ppm}$, respectively. Similarly, shoot numbers $3.3,2.13,4.2$ and 3.5 for the same concentrations.
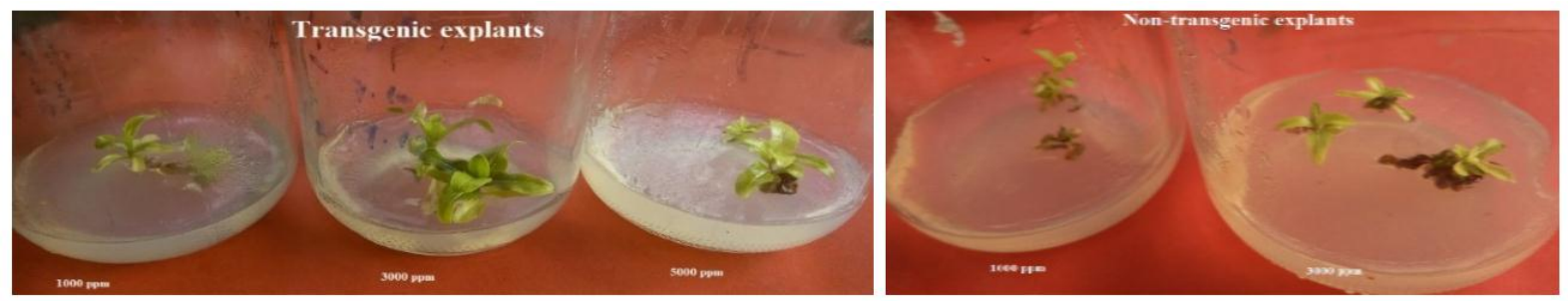

Fig 8. Effect of salinity concentrations on transformed and non-transformed explants growth

On the other hand, the non-transformed plants were more sensitive to salinity compared with transformed plants as they were un survive at salt concentration more than $1000 \mathrm{ppm}$.

In general, the results showed that the percentage of reduction of survival, shoot length, shoot number and leaves number as well as their necrosis percentage were affected by different salinity concentrations, with a maximum reduction at $5000 \mathrm{ppm} \mathrm{NaCl}: \mathrm{CaCl}_{2}$ treatment. Also, the growth of shootlets of transformed plants were less affected by different $\mathrm{NaCl}: \mathrm{CaCl}_{2}$ levels as compared to their non transformed (control) plants.

\section{b. Confirmation of the integration of $\mathrm{HVAl}$ transgenes via HPLC}

The yield of vincristine was determined by HPLC in transformed plants, non-transformed and seeds. The $H V A-1$ transformed plants survived at $5000 \mathrm{ppm}$ and non-transformed plants served as negative controls. The results showed that the production of vincristine increased in respose to salinity all transformants (Figure 9).

The amount of vincristine was $2.53 \mu \mathrm{g} / \mathrm{g}$ (fW) in transformed plants with overexpressed $H V A-1$ and about $0.025 \mu \mathrm{g} / \mathrm{g}$ (fW) in non- transformed plants. Especially at the end of culture (4 weeks), the accumulated vincristine was observed in the transformed plants compared with control. On the other hand, data in table (2) exhibited proline content which showed a significant effect between treatments in transformed explants and control $(9.71,9.16,8.23$ and 2.23 , respectively).

This finding is consistent with the real-time PCR results (data not shown), which suggests that $H V A-1$ expression is associated with the accumulation of vincristine. However, further investigations will be needed involving a greater number of transformed plants to decipher the precise role of $H V A-1$ genes in the regulation of TIAs pathway in $C$. roseus. 

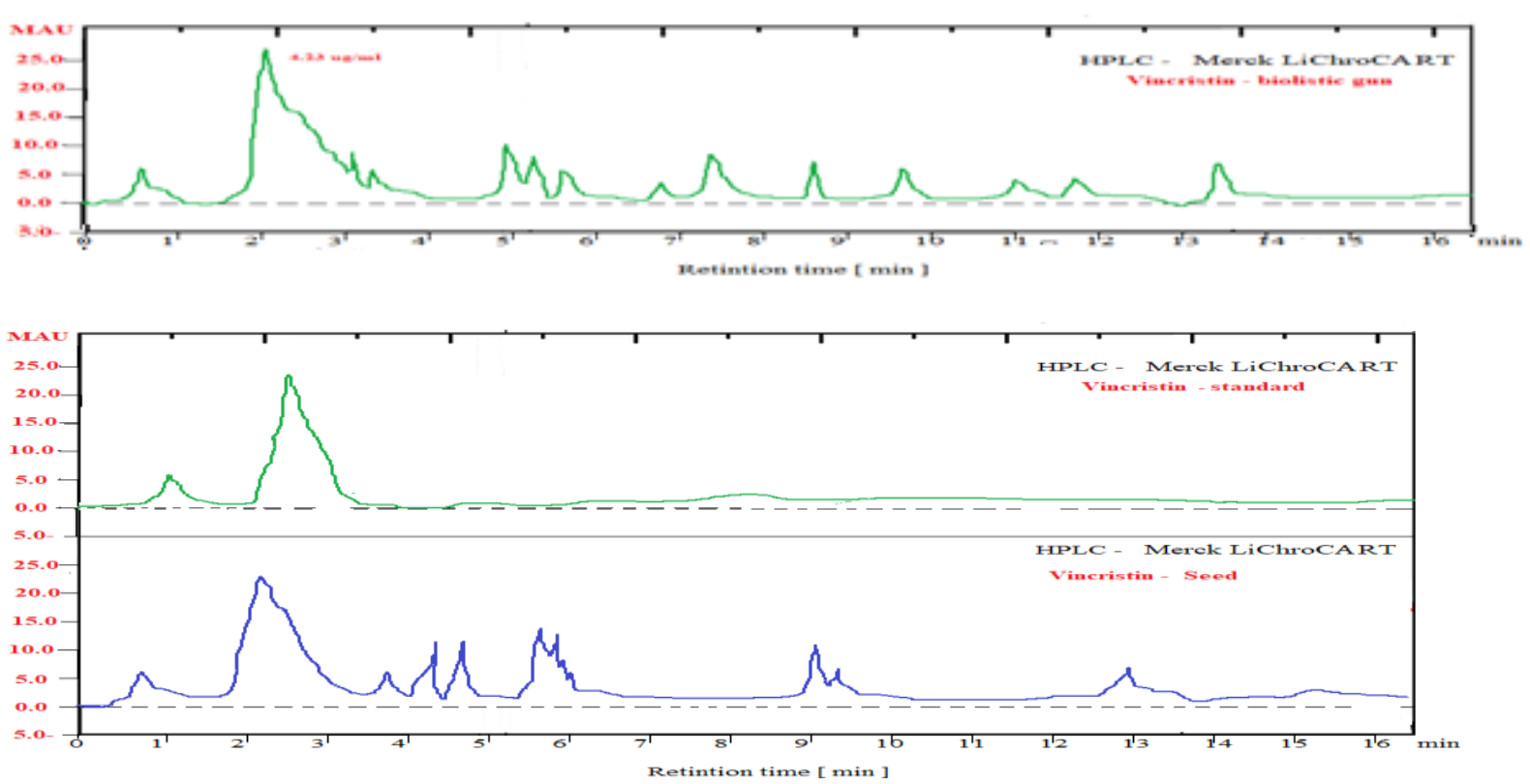

Fig. 9. HPLC chromatogram showed the quantity of vincristine in both transformed explants by biolistic gun, seeds and standard.

Because the transformation of $C$. roseus at whole plant level had no report before, the functions of genes in TIAs (Total indole alkaloids) were investigated using hair root or suspension cell transformation so far. Here the established transformation system

provides a potential possibility to investigate the effect of gene expression upon the alkaloids yields on $C$. roseus whole plant, and would contribute to the successful modification of the medicinal plants for higher natural product yields.

Table 3. HPLC chromatogram showed the quantity of vincristine in both transgenic explants by biolistic gun, Seeds and standard.

\begin{tabular}{lcc}
\hline Source of explant produced vincristine & Retention time & Vincristine $\mathrm{ug} / \mathrm{g}$ \\
\hline Transformed explant biolistic gun & 3.00 & 2.530 \\
Seeds (control) & 3.00 & 0.025 \\
Vincosien ® Standard & 3.00 & 5.000 \\
\hline
\end{tabular}

The present work achieved the transformation of C. roseus plants with the HVAl gene to confer resistance to salinity, by means of biolistic bombardments using whole plasmids or genetic blocks. Table 3 summarizes the results of transformed explants that exposed to the highest concentration of salinity (5000 ppm) comparison with non-transformed explants (Control seeds)

This technique for genetic modifications has been used by Fu, et. al., (2000) and Breitler, et al., (2002) to transform rice by means of biolistic, without a significant loss of transformation efficiency nor affecting the responses of bombarded explants regarding survival or regeneration, in comparison with the use of whole plasmid DNA. Those authors also pointed out that the rice plants transformed by genetic cassettes exhibited simple integration patterns and low frequencies of transgene rearrangements (less than those observed with the use of whole plasmid). This favours the stable expression of the transgene and improves biosafety as less foreign rearranged sequences become inserted in the bombarded tissues. This also reduces or eliminates the possible risk of horizontal or vertical transfer of genes for the resistance to antibiotics or herbicides, used as selection marker genes in the transformation procedure.

Recently, Vianna, et al., (2004) transformed bean plants by biolistic using a genetic cassette containing the bar gene, and their findings agree with those of $\mathbf{F u}$, et al., (2000) and Breitler, et. al., (2002). The use of the whole plasmid could cause plasmid-plasmid recombination events brought about by sequences rich in A-T (i.e. highly recombinogenic) on the backbone of the transformation vectors, which in turn might be involved in plasmid multimerization events $(\mathbf{F u}$, et. al., 2000).

Our own findings did not reveal any statistically significant differences between responses of tissues bombarded about survivorship, regeneration and detection by PCR, either with the whole plasmid, in agreement with other results published elsewhere. Anyhow, the advantage of using limited genetic blocks appears to support transgenic stability expression and inheritance over a long range. Our results tested by PCR incorporated the HVAl gene showed that five colonies of plantlets, three had a single band agreeing with the positive band, indicating the present of foreign gene. Additionally, two colonies 
did not have the one corresponding to the foreign gene, as was shown in Figure 7 .

Several hypothesis could explain the lack of expression at mRNA level; one of them could be the sensibility of the test, and as reported by Matzke and Matzke (1995), Hiei et al. (1994) and Kumpatla et al. (1997), this can be due to genetic rearrangements, gene silencing by insertion in transcriptionally inactive or highly repetitive regions, or by methylation. The transformation obtained in this study was performed without the use of markers of selection (except bar and kanamycin) or report genes. However, the marker genes are important to establish the procedure of transformation, for this reason, the parameters for transformation by bombardment were previously established using the plasmid pCAMBIA3201 De Guglielmo et al, (2010).

De Guglielmo et al, (2010) used the gus gene as areporter gene and found that . The best conditions were selected according to the survivorship and the expression of gus. It is remarkable, that even though gus is considered transient, the expression of this gene was observed seventeen months after bombardment of torpedo shape embryos. Bombardments with pCAMBIA3201 were made in parallel with those of the gene crylac, they were done as a control for the procedure, and to have a faster and easier procedure to follow the procedure of transformation, this control showed gus expression in all the experiments of bombardments.

In conclusions, the obtained results showed that particle gun can be used for the introduction of useful HVAl gene into the common vinca genome and indicated that the technique is useful in the recovery of engineered plants by transformation of regenerable embryogenic tissues. The bombardment was carried out using Gene booster TM driven by compressed Helium gas. The protocol used in the experiments gave promising results for the efficient regeneration and subsequent genetic transformation of $C$. roseus explants. The resulted transformed events were selected for only one marker salinity stress. Tolerant regenerated shoots, and plants showed greater osmotically tolerance to salinity stress in the regenerated plantlets. This research describes a method for high-efficient recovery of transgenic vinca plants, by tolerance to the salinity stress, multiple shoot induction from cotyledonary node meristematic tissues and biolistics techniques. Theoretically, the particle gun can be used to deliver DNA fragments into any kind of tissues but transgenic plants can be produced only from tissues capable of regenerating buds and shoots.

\section{References}

Ajenifujah-Solebo, S.O.A.; Isu, N.A.; Olorode, O. and Ingelbrecht, I. (2013). Effect of cultivar and explants type on tissue culture regeneration of three Nigerian cultivars of tomatoes. Sustainable Agriculture Research, 2 (3): 58-64.
Aniruddha, D. and Srivastava, P. (1997). Variation in vinblastine production by Catharanthus roseus, during in vivo and in vitro differentiation. Phytochem 46: 135-137.

Babu, R.; Zhang, J.; Blum, A.; Ho, T-H.; Wu, R. and Nguyen, H. (2004). HVA1, a LEA gene from barley confers dehydration tolerance in transgenic rice (Oryza sativa L.) via cell membrane protection. Plant Sci 166:855-86.

Bates, L.S., Waldren, R.P. and Teare, I.D. (1973). Rapid Determination of Free Proline for Water Stress Studies. Plant and Soil, 39, 205-207.

Bhatia, P. and Ashwath, N. (2008). Imrpoved the quality of in vitro cultured shoots of tomato (Lycopersicon esculantum Mill cv. Red Coat). Biotechnology, 7(2): 188 - 193.

Breitler, J., Labeyrie, A., Meynard, D., Legave, T. and Guiderdoni, E., 2002. Efficient microprojectil bombardment-mediated transformation of rice using gene cassettes. Theoretical and Applied Genetics, vol. 104, no. 4, p. 709-719

Bunnag, S.; Piyada, T.; Praweena, M.; Duangkamol, T. and Jirapat, C. (2006). An effective protocol for clonal propagation of "Proh Phu "(Caulokaempferia thailandica Larsen), K. Ku Researchs Journal, 11(2):1454-1463.

Canel, C.; Lopes-Cardoso, M.; Whitmer, S.; Vander Fits, L.; Pasquali, G.; Van-der Heijden, R.; Hoge, J. and Verpoorte, R. (1998). Effects of over-expression of strictosidine synthase and tryptophan decarboxylase on alkaloid production by cell cultures of Catharanthus roseus. Planta. 205(3):414-419.

Chiu, W.; Niwa, Y.; Zeng, W.; Hirano, T.; Kobayashi, H. and Sheen, J. (1996). Engineered GFP as a vital reporter in plants. Curr. Biol. 6: 325- 330

Choi, P.; Kim, Y.; Choi, K.; Chung, H.; Choi, D. and Liu, J. (2007). Plant regeneration from hairyroot cultures transformed by infection with Agrobacterium rhizogenes in Catharanthus roseus. Plant Cell Rep, 22(11):828-831.

Choudhury, S. and Gupta, K. (1995). Studies on the germination mechanism of Catharanthus roseus (L.) G.Don cv. alba seeds: effects of temperature and promoters. Seed Sci. Technol. 23: 831-842.

Close, B.; Hong-Brown, L.; Biwersi, J.; Verkman, A. and Welch, W. (1996). Chemical chaperones correct the mutant phenotype of the $\Delta$ F508 cystic fibrosis transmembrane conductance regulator protein. Cell Stress Chaperones 2: 117-125.

De Guglielmo-Cróquer, Z., Altosaar, I., Zaidi, M. and Menéndez-Yuffá, A. (2010). Transformation of coffee (Coffea Arabica L. cv. Catimor) with the crylac gene by biolistic, without the use of markers. Braz. J. Biol., 2010, vol. 70, no. 2, p. 387393

Diab, E. E. E. and Mohamed, S. E. (2008). In vitro morphogenesis and plant regeneration of bamboos 
(Oxytenanthera abyssinica A. Rich. Munro). International Journal Sustain. Crop Production, 3(6):72 - 79 .

Di-Cosmo, F . (1990). Strategies to improve yields of secondary metabolites to industrial interesting levels. In: Progress in plant cellular and molecular biology. pp: 717-725. H. J. Nijkamp et al. (eds), kluwer Academic Publisheres, London.

Duncan, D.B. (1955). Multiple range and multiple Ftests. Biom., 11: 1-42.

Dure L (2001) Occurrence of a repeating 11-mer amino acid sequence motif in diverse organisms. Protein Pept Lett 8 115-122

Dure L (1993) Structural motifs in Lea proteins. In: Close TJ, Bray EA (eds) Plant responses to cellular dehydration during environ-

Duzyaman, E.; Tanrisever, A. and Gunver, G. (1994). Comparative studies on regeneration of different tissues of tomato in vitro. Acta Hort., 235-242.

Eissa, A.E. (2013a). Genetic transformation of common beans (Phaseolus vulgaris L.) calli by biolistic gun and via Agrobacterium tumefaciens. Egyp. J. Gen. Cytol. 42(1): 1- 20.

Eissa, A.E. (2013b). Genetic transformation and regeneration of common bean (Phaseolus vulgaris L.) using Agrobacterium system. Egyp. J. Gen. Cytol. 42(1): 127-150.

Fernandez, J. A.; Owen, T. G.; Kurz, W. G. and De-Luca, V. (1989). Immunological detection and quantitation of tryptophan decraboxylase in developing Catharanhtus roseus seedlings. Plant Physiology, 91:79-84.

Fu, X., Duc, L., Fontana, S., Bong, B., Tinjuangjun, P., Sudhakar, D., Twyman,R., Christou, P. and Kholi, A., 2000. Linear transgene construct lacking vector backbone sequences generate low copy number transgenic plants with simple integration patterns. Transgenic Research, vol. 9, no. 1, p. 11-19.

Goday A, Jensen AB, Culianez-Macia FA, Mar Alb(s M, Figueras M, Serratosa J, Torrent M, Pages M (1994) The Inaize abscisic acidresponsive protein Rabl7 is located in the nucleus and interacts with nuclear localization signals. Plant Cell 6: 351-360.

Gomez, K.A. and Gomez, A.A. (1984). Statistical Procedures for Agricultural Research. 2nd Ed. John Wiley and Sons Ltd., New York, 680p.

Gopikrishna, V., Baweja, P. S., Venkateshbabu, N., Thomas, T. and Kandaswamy, D. (2008) Comparison of coconut water, propolis, HBSS, and milk on PDL cell survival; Journal of Endodontics; 34, 587-589

Gunay, A.L. and Rao, P.S. (1980). In vitro propagation of hybrid tomato plants (Lycopersicon esculentum L.) using hypocotyl and cotyledon explants. Annals of Botany, 45: 205-207.

HIEI, Y., OHTA, S., KOMARI, T. and KUMASHIRO, T., 1994. Efficient transformation of rice (Oriza sativa) mediated by Agrobacterium and sequence analysis of the boundaries of the T-DNA. The Plant Journal, vol. 6 , no. 2 , p. 271-282

Hong B, Barg R, Ho THD (1992) Developmental and organ-specific expression of an ABA- and stress-induced protein in barley. Plant Mol Biol 18:663-674.

Ingram, J. and Bartels, D. (1996) The molecular basis of dehydration tolerance in plants. Annual Review of Plant Physiology and Plant Molecular Biology, 47, 377-403.

Kashamanika, H. and Niranji, G. (1995). Propagation of Bambusa vulgaris (Yellow bamboo) through nodal bud culture. Journal of Horticulture Science, 70(3):469 - 475.

Klein TM, Gradziel T, Fromm MF, Sanford J (1988) Factors influencing gene delivery into Zea mays cells by high-velocity microprojectiles. BioTechnol. 6: 559-563.

Kumpatla, S., Teng, W., Buchholz, W. and Hall, T., 1997. Epigenetic transcriptional silencing and 5Azacytidine-mediated reactivation of a complex transgene in rice. Plant Physiology, vol. 115, no. 2, p. 361-373.

Kwapata, K., R. Sabzikar, M. B. Sticklen, and J. D. Kelly, (2009). In vitro regeneration and morphogenesis studies in common bean," Plant Cell, Tissue and Organ Culture, vol. 100, no. 1,pp. 97-105, 2009

Magnotta M, Murata J, Chen J, De Luca V. (2007). Expression of deacetylvindoline- 4-Oacetyltransferase in Catharanthus roseus hairy roots. Phytochemistry 2007, 68(14):1922-1931.

Maqbool SB, Zhong H, El-Maghraby Y, Ahmad A, Chai B, Wang W, Sabzikar R, Sticklen MB (2002) Competence of oat (Avena sativa L.) shoot apical meristems for integrative transformation, inherited expression, and osmotic tolerance of transgenic lines containing hva1. Theor Appl Genet 105:201-208

Matzke, M. and Matzke, A., 1995. How and why do plants inactivate homologous (Trans)genes? Plant Physiology, vol. 107, no. 3, p. 679-685.

Maxwell, S. E., and Delaney, H. D. (1990). Designing experiments and analyzing data: A model comparison perspective.

McKersie BD, Bowley SR, Harjanto E, Leprince O (1996) Water-deficit tolerance and field performance of transgenic alfalfa overexpressing superoxide dismutase. Plant Physiol 111:11771181

Mondal, T. K.; Bhattacharya, A.; Sood, A. and Ahuja, P. S. (2002). Propagation of tea (Camellia sinensis (L.) O. Kuntze) by shoot proliferation of alginate-encapsulated axillary buds stored at $4^{\circ} \mathrm{C}$. Current Science, 83(8):941 - 944.

Murashige T, Skoog F (1962) A revised medium for rapid growth and bioassay with tobacco tissue cultures. Physiol Plant 15:473-497 
Naghmouchi, S.; Khouja, M. L.; Rejeb, N. M. and Boussaid, M. (2008). Effect of growth regulators and explants origin on in vitro propagation of Ceratonia siliqua L. via cuttings. Biotechnology of Agronomy Socessity Environmental, 12 (3):251258.

Namedo, A. G. (2007). Plant cell elicitation for production of secondary metabolites: A review Pharamacogoncy Review, 1 (2-3): 69-79.

Oraby, H. F.; S. B. Maqbool, H. Zhong, and M. B. Sticklen, (2009). Transformation of oats and its application to improving osmotic stress tolerance," Methods in Molecular Biology, vol.478, pp. 149-168, 2009.osmotic stress tolerance," Methods in Molecular Biology, vol.

Phillipson, J. D. (1990). Plants as source of valuable products. In : Secondary Products from Plant Tissue Culture. pp. 1-23. Charwood, B.V. and Rhods, M. J. C. (eds.). Oxford Press, New York.pp. 97-105, 2009

Qu Y, Easson MLAE, Froese J. (2015). Completion of the seven-step pathway from tabersonine to the anticancer drug precursor vindoline and its assembly in yeast. PNAS USA 11:6224-6229

Quan Wang†, Shihai Xing, Qifang Pan, Fang Yuan, Jingya Zhao, Yuesheng Tian, Yu Chen, Guofeng Wang and Kexuan Tang (2012). Development of efficient catharanthus roseus regeneration and transformation system using agrobacterium tumefaciens and hypocotyls as explants. BMC Biotechnology, 12:34.

Rafael Zarate, Johan Memelink, Robert van der Heijden1 \& Robert Verpoorte (1999) Genetic transformation via particle bombardment of Catharanthus roseus plants through adventitious organogenesis of buds. Biotechnology Letters 21: 997-1002.

Rischer H, Oresic M, Seppanen-Laakso $T$ et al (2006) Gene-tometabolite networks for terpenoid indole alkaloid biosynthesis in Catharanthus roseus cells. PNAS USA 103:5614-5619

Rohila JS, Jain RK, Wu R (2002) Genetic improvement of Basmati rice for salt and drought tolerance by regulated expression of a barley Hva1 cDNA. Plant Sci 163:525-532.

Saxena, S. and Dhawan, V. (1999). Regeneration and large-scale propagation of bamboo (Dehdrocalamus strictus Ness) through somatic emberyogensis. Plant Cell Reports, 18(50: 438 443.

Schutze, R. and Wieczorrek, G. (1987). Investigations into tomato tissue cultures. I. Shoot regeneration in primary explants of tomato. Arch. Zuchtungsforschung, 17: 3-15

Sivamani E, Bahieldin A, Wraith JM, Al-Niemi TS, Dyer WE, Ho T-HD, Qu RD (2000) Improved biomass productivity and water use efficiency under water deficit conditions in transgenic wheat constitutively expressing the barley HVA1 gene. Plant Sci 155:1-9.
Srivastava T, Das S, Sopory SK, Srivastava PS. (2009). A reliable protocol for transformation of Catharanthus roseus through Agrobacterium tumefaciens. Physiol. Mol. Biol. Plants 2009, 15(1):93-98.

St-Pierre B, Vazquez-Flota FA, De-Luca V (1999) Multicellular compartmentation of Catharanthus roseus alkaloid biosynthesis predicts intercellular translocation of a pathway intermediate. Plant Cell 11: 887-900

Thio, G. L. (1982). Small-scale and home processing of fresh coconut (Oil Manufacture) and utilization of by-products. Department of Agriculture, Royal Research Institute Bulletin No. 209.

Van der Fits L, Memelink J. (1997). Comparison of the activities of CaMV $35 \mathrm{~S}$ and FMV $34 \mathrm{~S}$ promoter derivatives in Catharanthus roseus cells transiently and stably transformed by particle bombardment. Plant Mol Biol 1997, 33 (5):943946.

Van der Heijden R, Jabos DJ, Snoeijer W et al (2004) The Catharanthus alkaloids: pharmacognosy and biotechnology. Curr Med Chem 11: 1241-1253

Verma P, Mathur A., (2011). Agrobacterium tumefaciens-mediated transgenic plant production via direct shoot bud organogenesis from preplasmolyzed leaf explants of Catharanthus roseus. Biotechnol Lett 2011, 33 (5):1053-1060.

Verma P, Mathur AK, Srivastava A, Mathur A (2012) Emerging trends in research on spatial and temporal organization of terpenoid indole alkaloids pathway in Catharanthus roseus: a literature up-date. Protoplasma 249:255-268

Vianna, GR., Albino, MMC., Dias, Bba., Rech, EL. and Aragão, FJL., 2004. Fragment DNA as vector for genetic transformation of bean (Phaseolus vulgaris L.). Scientia Horticulturae, vol. 99, no. 3-4, p. 371-378. vitro regeneration and morphogenesis studies in common

Wang X, Pan YJ, Chang BW et al (2016) Ethyleneinduced vinblastine accumulation is related to activated expression of downstream TIA pathway genes in Catharanthus roseus. BioMed Res Int. doi:10. 1155/2016/3708187

Whitmer S, Canel C, van der Heijden R, Verpoorte R. (2003). Long-term instability of alkaloid production by stably transformed cell lines of Catharanthus roseus. Plant Cell Tiss Org Cult 2003, 74(1):73-80.

Wise MJ (2003) LEAping to conclusions: a computational reanalysis of late embryogenesis abundant proteins and their possible roles. BMC Bioinformatics 4:52

Xu D, Duan X, Wang B, Hong B, Ho T-HD, Wu R (1996) Expression of a late embryogenesis abundant protein gene, HVA1, from barley confers tolerance to water deficit and salt stress in transgenic rice. Plant Physiol 110:49-257. 
Yadav, N. R. and M. B. Sticklen (1995). Direct and efficient plant regeneration from leaf explants of (Sola-num tuberosum L.) cv. Bintje. Plant Cell Rep., 14: 645-647
Zhao J, Verpoorte R (2007) Manipulating indole alkaloid production by Catharanthus roseus cell cultures in bioreactors: from biochemical processing to metabolic engineering. Phytochem Rev 6:435-457.

$$
\begin{aligned}
& \text { التحسين الوراثي لصفة تحمل الاجهاد البيئي قي نبات الونكا بنق جين HVA-1 باستخدام قاذف الجينات }
\end{aligned}
$$

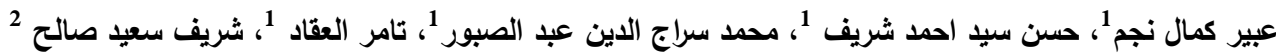

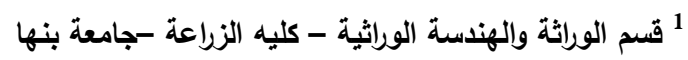

$$
\begin{aligned}
& 2 \text { قسم بحوث النباتات الطبية والعطرية - معمل زراعه الأنسجة - معهل بحوث البساتين - مركز البحوث الزراعية }
\end{aligned}
$$

هدفت هذه الدراسة الي ادخال جين تحمل الملوحة HVA1 الى خلايا الكالس لنبات الونكا من خلال استخدام تكنيك قاذف الجينات من خلال انتاج

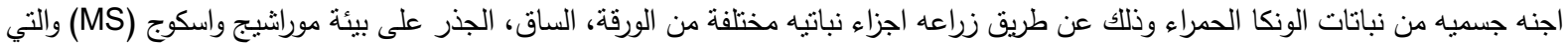

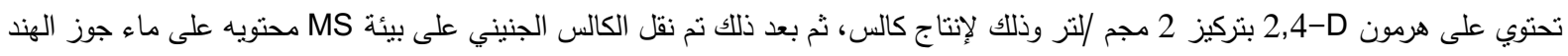

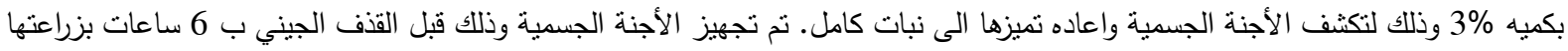

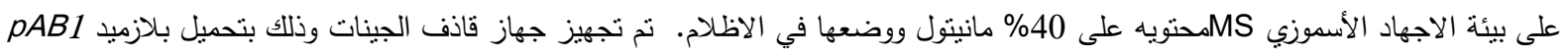
المحتوى على جين HVA1 على جزيئات الذهب قطرها ميكرون 1.0

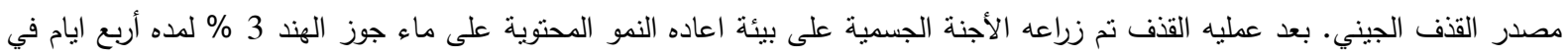

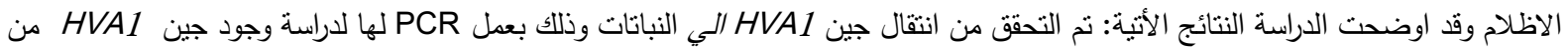

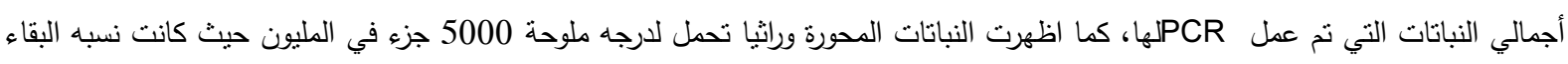
79.2 \% مقارنه بالنباتات الغير محوره وراثيا والتي تحملت ملوحة فقط 1000 جزء في المليون بنسبه 70.25 \% . الكلمات الداله : الونكا - الاجنه الجسميه - نقل الجينات - جين HVA1 لتحمل الملوحه - الفينكريستين 